Chigwata, T. C. et al. (2017). Ministerial directives to local government in Zimbabwe: topdown governance in a decentralized constitution. Journal of African Law, 61(1): 41-56

\title{
Ministerial directives to local government in Zimbabwe: top-down governance in a decentralized constitution
}

\author{
Tinashe Carlton Chigwata, Varaidzo Violet Muchapondwa and Jaap de Visser
}

\begin{abstract}
Urban and rural local authorities constitute the lowest tier of Zimbabwe's multilevel system of government. These local governments have a constitutional "right to govern" that must be exercised within the constitutional, legislative and policy framework. Under the old constitutional order, the national government could supervise urban local authorities, for example by issuing policy directives to ensure that these authorities governed in a manner that enabled them to deliver on national and local goals. This article examines this supervisory instrument, the powers it gives the national government, its use in practice and its relevance under the new constitutional order. The main argument is that supervisory instruments, such as the power to issue policy directives to local governments, are necessary in any multilevel system of government. However, such supervisory powers must be balanced with the need for local autonomy, to allow local governments to deliver on their service delivery obligations and development mandate.
\end{abstract}

\section{Introduction}

Despite serious criticism with regard to the political and legislative process leading up to its adoption, ${ }^{1}$ Zimbabwe's 2013 Constitution (the Constitution) ${ }^{2}$ has the potential to put the country on a path towards greater democratization and respect for human rights. One of the Constitution's many new dimensions is that it provides for national, provincial and local levels of government, thus entrenching a multilevel system of government. Section 5 of the Constitution now makes clear that Zimbabwe has three tiers of government. The significance of this is that provincial and local governments have been elevated from being mere creatures of statute into tiers of government that may only be abolished by a constitutional amendment. Zimbabwe's local government system, once regarded as a model on the continent, stands to benefit from this constitutional recognition. The Constitution goes beyond symbolic recognition of local government. In a provision that resembles a similar provision in the South African Constitution, 3 it guarantees the "right" of a local authority to "govern, on its own initiative, the local affairs of the people within the area for which it has been

\footnotetext{
${ }^{1}$ See W Zembe and CO Masunda "The global political agreement (GPA) constitution in Zimbabwe: A new peopledriven constitution or a misnomer?" in J de Visser, N Steytler, D Powell and E Durojaye (eds) Constitution-Building in Africa (2015, Nomos and Community Law Centre, University of Western Cape) 19.

${ }^{2}$ Constitution of Zimbabwe Amendment No 20 of 2013.

${ }^{3}$ Constitution of South Africa Act No 108 of 1996, sec 151(3).
} 
established". 4 The Constitution also provides that a local authority has all the powers necessary to do so. However, local governments must govern "subject to this Constitution and any Act of Parliament". 5 Local governments must therefore exercise their powers subject to supervision by national government, as provided for in the Constitution and any act of Parliament. This article examines a specific instrument of national supervision over local government: the issuing of national policy directives by the national executive, represented by the minister of local government (the Minister). It proposes a normative framework for the national supervision of local governments and then proceeds to examine the Minister's power to issue pol- icy directives under that framework. The examination is carried out against the backdrop of the Constitution, which has redefined relations between central and local government. The article starts by considering the development of the normative framework. It then examines the law pertaining to the issue of policy directives and looks at a number of examples to explore how the Minister uses this instrument in practice, before offering recommendations and conclusions.

\section{Framework for the supervision of local government}

The literature on decentralization often emphasizes that the allocation of decision-making power to local government can have many positive effects.

Bringing decision-making closer to communities enhances government's ability to gauge the needs of local communities and serve them more effectively. 6 Decentralization may also nurture tolerance across political divides, as it presupposes that different levels of government will take different decisions but will nevertheless have to work together.7 There are many more arguments that speak to the virtues of local discretion. However, the literature is also awash with expressions of caution: local discretion or local autonomy should be fettered in some way, as it could otherwise have negative consequences. For example, transferring taxing and spending powers to local governments may compound inequity: cities with buoyant tax bases can offer good services while rural local governments struggle to make ends meet and thus offer services of a lower standard. 8 Decentralization has also been associated with the threat of corruption. It is argued that the creation of multiple decision-making sites, many of them removed from the scrutiny of national media and national institutions, can create a fertile ground for increased corruption. 9 Notwithstanding the validity of these arguments, many, if not most, scholars of decentralization agree that decentralization should be implemented in a measured way and that national government should always retain

\footnotetext{
${ }^{4}$ Constitution, sec 276 .

${ }^{5}$ Ibid.

${ }^{6}$ P Smoke Fiscal Decentralisation in Developing Countries: A Review of Current Concepts and Practice (2001, UN Research Institute for Social Development) 6 at 8.

${ }^{7}$ See DT Sisk Democracy at the Local Level: The International Idea Handbook on Participation, Representation, Conflict Management, and Governance (2001, The International Institute for Democracy and Electoral Assistance) at 74; J Siegle and O'Mahony "Decentralisation and internal conflict" in E Connerley, K Eaton and P Smoke (eds) Making Decentralisation Work (2010, Lynne Rienner) 135 at 141.

${ }^{8}$ R Prud'Homme "The dangers of decentralisation" (1995) 10/2 The World Bank Observer 201 at 203; J de Visser Developmental Local Government: A Case Study of South Africa (2005, Intersentia) at 27.

${ }^{9}$ Prud'Homme, id at 211.
} 
a measure of oversight over the exercise of powers at decentralized level.1010 In other words, in any decentralization scheme, there will be a need for the national government to supervise local government. The dictionary definition of supervision is the "task of overseeing the activities and the conduct of another and making certain that everything is done correctly". ${ }^{11}$ National governments must exercise restraint when they do so because otherwise the benefits of decentralization may not be realized. ${ }^{12}$ What is required is a balance between the need for supervision and the need for local autonomy.

Supervision of local government can be exercised in various forms. ${ }^{13}$ At least three forms can be distinguished: regulation, monitoring and intervention. ${ }^{14}$ The primary focus of this article is on regulation, since this is the form of supervision most relevant to this study. A general definition of "regulation" is the "promulgation of an authoritative set of rules, accompanied by some mechanism, typically a public agency, for monitoring and promoting compliance with these rules". ${ }^{15}$ In the context of intergovernmental supervision, regulation refers to national government (or sometimes, provincial governments) determining legal frameworks, sets of parameters within which local autonomy can be exercised responsibly. ${ }^{16}$ If the benefits of local discretion and the ultimate aim of decentralization, which is local empowerment, are to be realized, such a framework should take into account a number of factors.

First, it should not extend to the core of how local governments must per- form the function in question but should be limited to framework legislation. A framework is defined as the basic, underlying structure to a set of regulations. ${ }^{17}$ It is the determination of minimum norms and standards rather than the usurpation of local power through overly intrusive or detailed regulation. ${ }^{18}$ Secondly, the framework should be predictable. Local governments should be able to anticipate the rules to which they are required to adhere and adjust their planning and budgeting accordingly. Continually changing the regulatory framework will jeopardize local government's ability to achieve optimal service delivery. ${ }^{19}$ Thirdly, differences

\footnotetext{
${ }^{10}$ See N Steytler and J de Visser Local Government Law of South Africa (2007, Lexis Nexis / Butterworths) at 5-15; de Visser Developmental Local Government, above at note 8 at 169-70; R Bahl "Implementation rules for fiscal decentralisation" (paper presented at the International Seminar on Land Policy and Economic Development, Land Reform Training Institute, Taiwan, 17 November 1998) at 8-9.

${ }^{11}$ M Waite and S Hawker (eds) Oxford Paperback Dictionary and Thesaurus (2nd ed, 2007, Oxford University Press) at 934.

${ }^{12}$ See UN Habitat International Guidelines on Decentralisation and the Strengthening of Local Authorities (2007) at 7; European Charter of Local Self-Government, Strasbourg, 15.X.1985.

${ }^{13} \mathrm{~N}$ Machingauta "Supervision of local government" in J de Visser, N Steytler and N Machingauta (eds) Local Government Reform in Zimbabwe: A Policy Dialogue (2010, Community Law Centre, University of the Western Cape) 139 at 140 .

${ }^{14}$ Steytler and de Visser Local Government Law, above at note 10, chap 15 at 5; N Steytler "Introduction" in N Steytler (ed) The Place and Role of Local Government in Federal Systems (2005, Konrad-Adenauer-Stiftung) 1 at 7. See Machingauta "Supervision of local government", above at note 13 at 143.

${ }^{15}$ R Baldwin, C Scott and C Hood "Introduction" in R Baldwin, C Scott and C Hood (eds) A Reader on Regulation (1998, Oxford University Press) 1 at 3.

${ }^{16}$ See de Visser Developmental Local Government, above at note 8 at 170.

${ }^{17}$ J Litvack and J Seddon (eds) Decentralisation Briefing Notes (1999, The World Bank) at 75.

18 Ibid.

${ }^{19}$ See de Visser Developmental Local Government, above at note 8 at 44 .
} 
between local governments should be accommodated in the framework. It is wrong to assume that all local governments have the same capability to comply with national legislation or face the same challenges. This is exactly why most countries divide local government into different categories on the basis of demographic features, levels of capability or even performance. Lastly, the subjects of the framework, ie the local governments themselves, should be consulted before the framework is determined, as they will ultimately be responsible for compliance. It is a good governance principle that, when a proposed decision may affect an institution or an organization, the interested parties must be consulted. ${ }^{20}$ Consulting local governments on the framework will result in better quality laws and in local governments being better informed about them. ${ }^{21}$ It has been argued that intergovernmental consultation has three basic elements. First, there must be an invitation to hear the views of a particular party. Secondly, there must be an adequate opportunity to submit considered views and, thirdly, the party inviting views must consider those views in good faith. ${ }^{22}$ It is important that local governments be informed before a decision is made so that they will be aware of the risks and drawbacks of the decision to be made.

The need for local government to adhere to nationally prescribed standards will come at a cost to local government. Therefore, compliance and implementation costs should also be considered when the framework is designed. A balance must be struck between the cost of compliance and the objectives of the framework. Confronting local authorities with sudden legal change that is costly to implement without paying attention to additional resources for those local authorities will compromise the viability of local governments. ${ }^{23}$

After having prescribed frameworks within which local governments are to exercise their powers, national government generally monitors legal compliance and the performance of local governments. This is necessary in order to detect early signs of problems that may require more drastic intervention by the appropriate authority. ${ }^{24}$

Intervention is the most intrusive form of supervision. 25 Depending on the constitutional design, decentralization schemes often involve mechanisms whereby the national government is empowered by the constitution or statutes to intervene in local authorities' affairs in response to abject service delivery failures, security threats, major emergencies or serious legal compliance issues. ${ }^{26}$ For example, in South Africa, intervention may entail measures such as the issuing of a directive, the

\footnotetext{
${ }^{20}$ BC Smith Good Governance and Development (2007, Palgrave MacMillan) at 156.

21 Ibid.

${ }^{22}$ Steytler and de Visser Local Government Law, above at note 10 at 22-134.

${ }^{23}$ See Organisation for Economic Co-Operation and Development "Reference checklist for regulatory decisionmaking", available at: <http://acts.oecd.org/Instruments/ShowInstrumentView.aspx?InstrumentID=128> (last accessed 3 February 2017).

${ }^{24}$ See Steytler and de Visser Local Government Law, above at note 10 at 260; Machingauta "Supervision of local government", above at note 13 at 142 .

${ }^{25}$ Y Hoffman-Wanderer and C Murray "Suspension and dissolution of municipal councils under section 139 of the Constitution” (2007) TSAR 141 at 141.
} 
takeover of municipal functions or the dissolution of a local government council.27 Legislation must clearly provide when intervention is the appropriate step to take when supervising local government. When the legislation is unclear with regard to when intervention can be triggered, the disciplinary responses from the higher governments can be numerous. ${ }^{28}$ According to Azfar et al, in the case of Uganda, as a result of the fact that the central government does not back policies with sanctions, when a local government underperforms in a key sector, the disciplinary measures are numerous. ${ }^{29}$ They further state that the disciplinary responses range from suspension or dismissal of the responsible bureaucrat to investigation by national authorities. ${ }^{30}$ Where there is no clear framework for when and how the central government may intervene, there is a danger that local autonomy will be undermined. ${ }^{31}$ Local autonomy is promoted and protected if attention is paid to a number of matters. First, the legal framework for intervention should include checks and balances to protect local government against the abuse of intervention powers by senior governments. Integral to this would be mechanisms for improved monitoring, an early warning system and strengthened means for intergovernmental oversight and support measures. Secondly, the mechanisms used to intervene in local government must be reviewable in court, so that there is recourse for local authorities that are of the opinion that the intervention power is being abused. Finally, when the problems giving rise to the intervention have been resolved, the intervention must be terminated. $3^{2}$

Having discussed a normative framework for the supervision of local governments with particular attention to the nature of an effective regulatory framework, this article now turns to the legal framework and practice in Zimbabwe. The following section will assess the Minister's powers to issue pol- icy directives under section 313 of the Urban Councils Act of 1995.33

\section{Supervisory powers of the minister responsible for local government}

The Minister has a range of powers and obligations under various local government laws. Key among them is the Urban Councils Act (UCA), which primarily regulates the activities of urban councils (local authorities or governments). UCA provides for national government, through the Minister, to supervise urban local authorities. The objective of this supervision by the national government is, among other things, to ensure efficient service delivery, curb and prevent corruption, and ensure that local authorities deliver on their development mandate.34 Under UCA, for instance, the

\footnotetext{
${ }^{26}$ de Visser Developmental Local Government, above at note 8 at 43-45.

${ }^{27}$ Constitution of South Africa, sec 139(1).

28 O Azfar, J Livingston and P Meagher "Decentralisation in Uganda" in P Bardhan and D Mookherjee Decentralization and Local Governance in Developing Countries: A Comparative Perspective (2006, MIT Press) 231.

${ }^{29}$ Ibid.

${ }^{30}$ Ibid.

${ }^{31}$ See Hoffman-Wanderer and Murray "Suspension and dissolution", above at note 25 at 141 .

${ }^{32}$ Steytler and de Visser Local Government Law, above at note 10 at 38. See also N Machingauta "A legal analysis of the appointment of caretakers to act as council in terms of Zimbabwe's section 80 of the Urban Councils Act" (2009, unpublished LLM thesis submitted at the University of the Western Cape) at 29-34.

${ }^{33}$ Chap 29:15.

${ }^{34}$ A Madhekeni and G Zhou "Legal and institutional framework: The 'Achilles Heel' of local authorities and raison d'être of ministerial intervention in Zimbabwe" (2012) 2/3 Journal of Public Administration and Governance 19 at 23.
} 
Minister is empowered to "direct a council to reverse, suspend or rescind any of its resolutions or decisions if he or she considers that the resolutions or decisions are not in the interest of the inhabitants of the area, or in the national or public interest". 35 The Minister may also appoint investigators to enquire into the affairs of any urban local authority. ${ }^{36}$ Furthermore, under section 313 of UCA, the Minister may give councils directives of a general nature on policy which the Minister deems to be in the national interest. These policy directives are often used by the national government to ensure that the activities of local authorities are in line with national policies and objectives. The directives are binding and must be complied with expeditiously, even if the local council disagrees with them.37 A similar provision exists in section 155 of the Rural District Councils Act, which empowers the Minister to take similar action with respect to rural councils. $3^{8}$ While phrased differently and not discussed in detail here, much of what is discussed with respect to section 313 of UCA also applies to section 155 of the Rural District Councils Act. The wide discretion given to the Minister to supervise local authorities has generated much debate within the local government sector. The reality is that urban local authorities are not delivering basic services efficiently and effectively. 39 This is attributed to a number of challenges, including the political and economic crisis in Zimbabwe. 40 However, there are also scholars who attribute this failure to undue interference in local government affairs by the Minister.41 It is safe to say that the Minister's power to issue policy directives is a controversial instrument in this respect.

Assessing the power of the Minister to issue policy directives Section 313 of UCA provides:

“(1) Subject to subsection (2), the Minister may give a council such directions of a general character as to the policy it is to observe in the exercise of its functions, as appear to the Minister to be requisite in the national interest.

1. Where the Minister considers that it might be desirable to give any direction in terms of subsection (1), he shall inform the council concerned, in writing, of his proposal and the council shall, within thirty days or such further period as the Minister may allow, submit to the Minister, in writing, its views on the proposal and the possible implications on the finances and other resources of the council.

2. The council shall, with all due expedition, comply with any direction given to it in terms of subsection (1)."

A number of features require closer scrutiny. First, the directive is issued to an individual council; what is the significance of that? Secondly, the directions must be "of a general character" and relate to policy. This is another aspect that defines the scope of the instrument. Thirdly, the directive may be issued if it is required "in the

\footnotetext{
${ }^{35}$ UCA, sec 314

${ }^{36} \mathrm{Id}, \sec 311$.

${ }^{37}$ Ibid.

${ }^{38}$ Chap 29:30.

39 See D Dewa, C Dziva and K Mukwashi "Exploring local governance challenges in Zimbabwe under the Government of National Unity era and beyond" (2014) 2/8 International Journal of Political Science and Development 188 at 189.

${ }^{40}$ Ibid.
} 
national interest", a phrase that deserves closer examination. Finally, the Minister must "inform" the council; what does this duty entail? A more detailed analysis of these issues will provide a clearer picture of how UCA envisages the Minister will use the power to issue directives.

\section{What is a council?}

Section 313(1) of UCA provides that the Minister may give "a council" policy directives. It further states that the Minister may inform "a council", when it is considered desirable to issue a directive. $4^{2}$ After the proposal, it is "the council" that must submit its views on the proposal. These views include the possible financial implications of the directive on "the council".43 Finally, it is the relevant council that must comply with any directive given under section 313(1).44 Section 2 defines a council as a "municipal council or town council". A local authority is another term used to refer to a municipal council, town council, district council or municipal board.45 It is evident from these provisions that the act intends that the policy directives are addressed to individual councils. This does not prevent the Minister from issuing policy directives to groups of urban local authorities or even to all urban local authorities. However, the Minister would have to ensure that each council in that group is engaged on the matter in terms of the provisions noted above.

\section{Policy directives of a general nature}

It was argued above that a supervisory regulatory framework must not be overly prescriptive about how local governments are to perform their functions. Rather, it must be limited to setting the framework within which local governments operate. Section 313(1) of UCA follows this approach when it provides that the Minister may issue "directions of a general character as to the policy [a council] is to observe in the exercise of its functions". It is submitted that a directive "of a general character" may specify the processes or procedures to be followed by an urban council. It may relate to a policy that the urban council must observe when exercising its functions. For example, a directive of a general nature may establish the minimum standards required for service delivery, establish minimum standards for public participation or prescribe the minimum content of certain policies or laws to be adopted by the local authority. However, if a directive specified in detail how an urban council is to operationalize the delivery of services or if it dictated the detail of how a local authority is to engage its community, it would go beyond the permitted "general character" of the directive. Similarly, if it provided the exact content of a local policy or law, it would go beyond what is permitted. In short, it is submitted that section 313 of UCA does not permit the Minister to use the directive to replace a local authority's decision with his or her own decision.

\footnotetext{
${ }^{41}$ Madhekeni and Zhou "Legal and institutional framework", above at note 34 at 20; S Chakaipa "Local government institutions and elections" in de Visser, Steytler and Machingauta (eds) Local Government Reform, above at note 13, 31 at 32 .

${ }^{42}$ UCA, sec 313(2).

43 Ibid.

${ }^{44} \mathrm{Id}, \sec 313(3)$.

${ }^{45} \mathrm{Id}$, sec 2.
} 


\section{The meaning of national interest}

It was argued earlier that the regulatory framework governing local government must be predictable. A continuously changing framework would be detrimental to a local authority's ability to achieve optimal service delivery. ${ }^{46}$ Section 313 provides that the Minister may give directions of a general nature on policy that the Minister deems to be requisite in the national interest. The "national interest" is a notoriously ambiguous concept for which there is no accepted common standard or definition.47 Section 313 allows wide discretion; the implication of this is that it is difficult for local authorities to anticipate what circumstances will prompt the Minister to invoke the provision. This is a recipe for differing views between the Minister and local authorities. When central and local governments have different views on what is in the national interest, the central government may make decisions that may under- mine or compromise the autonomy of urban councils in the name of the national interest. 48 It would have been better if UCA had specified the grounds upon which the Minister may invoke section 313. The phrase "as appear to the minister to be requisite in the national interests" 49 makes it clear that the act intends to afford the Minister wide discretion. The national interest imperative is not formulated as a jurisdictional fact, ie dependent on the existence of verifiable facts, but is based on the Minister's opinion. This will make it very difficult for anyone to challenge the Minister's reliance on the national interest criterion. It is apparent from section 313 that the act gives the Minister extraordinarily wide discretion to invoke this instrument. It is suggested that, based on the wording alone, this law impacts very negatively on a local authority's "right to govern" in section 276 of the Constitution and that it ought to be reconsidered as part of the alignment of local government laws with the new Constitution.

\section{The duty to inform an urban local authority before issuing policy directives}

It was argued earlier that, when laws or policies affecting local government are developed, local authorities must be consulted as they will be required to implement these laws or policies..$^{\circ}$ Section 313(2) of UCA provides that the Minister must inform the council concerned, in writing, of the proposal to issue a directive. Following the proposal, the council must, within a specified period, submit its views and the possible implications on the finances and other resources. ${ }^{51}$ This duty to inform entails that the Minister must provide the affected council with facts or information concerning the proposal. When making the final decision, he or she does not necessarily have to take the council's views into account because the act does not refer to consultation or the consideration of the council's views. ${ }^{2}$ When viewed in light of the considerations pertaining to supervision made earlier, this appears to be a short-coming in the text of section 313 of UCA. In addition, it is argued that this aspect is not in line with the new Constitution, which instructs the

\footnotetext{
${ }^{46}$ See de Visser Developmental Local Government, above at note 8 at 44.

${ }^{47}$ Machingauta "Supervision of local government", above at note 13 at 150 .

${ }^{48}$ See id at 141.

${ }^{49}$ UCA, sec 313(1).

${ }^{50}$ Smith Good Governance and Development, above at note 20 at 156.

${ }^{51}$ UCA, sec 313(2).

${ }^{52}$ See N Steytler and J de Visser Constitutional Law of South Africa (2nd ed, 2011, Juta) at 22-134.
} 
various components of the state to work together under the umbrella of the concept "cooperative government". Section 194(1)(g) of the Constitution provides that institutions and agencies of government at all levels must cooperate with each other. Furthermore, provincial, metropolitan and local authorities must cooperate with one another within their spheres, in particular by informing one another of and consulting one another on matters of common interest, harmonizing and coordinating their activities. 53 While the Constitution may not explicitly require central government to consult local government, a purposive reading of section 194 of the Constitution as a whole, together with other provisions of the Constitution pertaining to devolution, lead to the conclusion that the Constitution intended that central government consult provincial and local governments on matters of mutual interest. The text of section 313 of UCA therefore needs to be reconsidered. In addition, the application of section 313 must take into account these constitutional values. It is suggested that, notwithstanding the text of section 313, a failure of the national government to inform and consult a council before issuing policy directives goes against the constitutional provisions surrounding cooperative government.

\section{Examining the use of the power to issue policy directives in practice}

The previous section examined the Minister's powers to issue policy directives under section 313 of UCA. This section examines how this power has been used in practice. Particular attention is given to the ministerial directive on employment, issued in 2010 under section 313.

Before September 2010, most local authorities in Zimbabwe were in salary arrears and were failing to deliver on their statutory obligations, including the remittance of funds (medical and pensions) to the responsible institutions. This had adverse consequences on the welfare of employees and service delivery at large. In response to this, the ministry wanted all salary arrears to be cleared by the end of the 2010 financial year to allow councils to start the 2011 year with a clean slate. In a bid to rationalize employment costs and to ensure that a large portion of arrears owed to pension, medical and other institutions was reduced, Minister Dr Ignatious Chombo issued a directive on employment to all local authorities.54 The directive stipulated that no local authority was to employ any staff member at any level or grade, without the Minister's written permission; local authorities were required to make representations to the Minister where compelling reasons existed for recruitment. The directive read:

"It has been observed that most local authorities are in salary arrears to a varying extent and are also in arrears in the remittances of statutory obligations, which will ultimately affect the workforce.

\footnotetext{
${ }^{53}$ Constitution, sec 265(1)(d).

${ }^{54}$ Ministry of Local Government, Rural and Urban Development "Ministerial directive on employment" (29 September 2010).
} 
It is the desire of the Ministry that all salary arrears are cleared by the end of this financial year to allow Councils to start 2011 on a clean slate. It is also expedient that a larger portion of statutory obligations owing is cleared.

In view of this, the following directive is made in terms of [sic] 313 of the Urban Councils Act and Section 155 of the Rural District Councils Act.

With immediate effect no local authority may employ any staff member at any level or grade, including casual or contract workers, without the written permission of the Minister. Where compelling reasons exist for recruitment these should be submitted, together with details of employment costs and the relevant revenue source, to the Minister for his consideration.

This directive is not designed to hinder Councils in their operations but to rationalise the employment costs and the need to clear salary and statutory obligation arrears.

This article will assess this directive against the backdrop of the provisions of UCA and the considerations that were discussed concerning the normative framework for supervision. In short, it will explore whether the directive is limited to setting standards, whether the use of the instrument was predict- able, whether differences at local level were accommodated, whether local governments participated in the formulation of the directive and whether implementation costs were considered.

\section{Was the directive limited to setting standards?}

The first question is whether this directive was of a "general character", as pre- scribed by section 313 of UCA. It is argued that the directive went beyond the permissible "general character". It required a specific act, namely written approval from the Minister, before a local authority could recruit. It is evident from the directive that local authorities were not only failing to pay salaries, but were also failing to comply with their statutory obligations. If the objective of the directive was to enable councils to start 2011 on a clean slate, the Minister could perhaps have proposed standards that promoted sound financial management. Alternatively, the Minister could have issued minimum standards for recruitment. However, the Minister opted to usurp each local authority's power to appoint staff altogether.

\section{Was the directive predictable?}

The second question is whether the directive on employment was predictable. In other words could local authorities have foreseen this directive and could they have adjusted their operations perhaps to avoid it? An analysis of the background to the directive shows that there is no doubt that the national government had to use its supervisory powers to ensure that the challenges were addressed. The directive on employment included clear goals to ensure that local authorities met their statutory obligations and eliminated salary arrears. Hence, it can be argued that the directive was reasonably predictable. 


\section{Did the directive accommodate differences at the local level?}

The third question is whether the directive on employment accommodated differences at the local level. Not all local authorities displayed exactly the same level of compliance with their statutory obligations. However, the directive treated all local authorities the same. Even those local authorities that were paying their staff on time were required to seek the Minister's approval before recruiting staff. It is argued that the directive should have differentiated between local authorities that were meeting their statutory obligations and thus did not have salary arrears and those that did not. If that distinction had been applied, the intensive monitoring and approval regime may have been appropriate.

\section{Were the local councils involved in the determination of the directive?}

The next question is whether local authorities participated in the determination of the directive on employment. In other words, were local authorities consulted before the directive was issued? There is no evidence to suggest that urban councils were consulted before it was issued. In fact, it seems that local authorities were not even afforded the opportunity, as required under section 313(2) of UCA, to submit their views on the proposed directive. Instead, the directive itself invites local authorities to apply to the Minister if they have "compelling reasons" to recruit staff. Urban authorities were thus not permitted to make representations on a policy that was going to have significant consequences for their operations. It is submitted that this runs contrary to the principle of cooperative government that is a key component of the Constitution.55

\section{Were compliance or implementation costs considered?}

The final question is whether compliance or implementation costs were taken into account before the directive was issued. The effect of the directive was going to be that no local authority could recruit personnel without the Minister's written approval. In the event that there were "compelling reasons" to recruit staff, the directive required the relevant local authority to appeal to the Minister. Therefore, day to day recruitment decisions, essential to the operations of any local authority, were suddenly imbued with procedural rigour that required communication with the ministry in Harare. It goes without saying that the Minister could have foreseen that the directive would impose additional bureaucratic costs onto local authorities, diverting resources away from service delivery. In addition, the delays in filling critical vacancies would impact the local authority's ability to discharge its functions. However, nothing in the directive suggests that these costs were taken into account or balanced in any way against the objective of the directive.

In summary, the directive was not "of general character" as it effectively removed local decision-making authority and placed this with the Minister. Although the directive could have been predictable, it did not accommodate differences at the local level. There is also no evidence to suggest that local authorities were consulted before the directive was issued or that implementation costs were considered.

${ }^{55}$ Constitution, secs 194(1)(g) and 265. 


\section{Is section 313 of the urban councils act consistent with the 2013 constitution?}

This article has argued that section 313 of UCA gives the Minister very wide powers and that the implementation of this provision in the case of the employment directive is a sign that the regime for supervising local government does not balance local discretion with the need for central oversight. As the Constitution guarantees local authorities some measure of autonomy, it is also appropriate to judge section 313 of UCA and the manner in which it is implemented against this new constitutional framework. Section 2 of the Constitution states that the Constitution is the supreme law of Zimbabwe and any law, practice, custom or conduct that is inconsistent with it is invalid to the extent of its inconsistency.

As highlighted above, section 276(1) of the Constitution guarantees every urban local government the "right to govern" on "its own initiative" the affairs of its communities. It gives local governments "all" the powers necessary to "govern", subject to the Constitution and national legislation. ${ }^{56}$ This provision recognizes the importance of the autonomy of local authorities.57 In the con- text of the South African Constitution, which uses very similar terminology, Steytler and de Visser argue that the use of the word "right" emphasizes that a local authority is entitled to govern the affairs of its own communities and that this entitlement can be claimed and defended in terms of the constitution. $5^{8}$ They further argue that the phrase "on its own initiative" marks the end of the era when municipalities were the implementers of national and provincial legislation and had no policy making authority of their own.59 While the Constitution does not explicitly provide for the supervisory powers of the national government, it provides values and principles which should inform how the national government supervises local authorities.60 Thus, while other tiers of government may supervise the functioning of local government, this must be done without encroaching on the institutional integrity of local government. Section 265(1)(c) of the Constitution provides that, when different levels of government are exercising their functions, they must do so in a manner that does not encroach on the geographical, functional or institutional integrity of another tier of government.

Section 313 of UCA provides that the Minister may issue policy directives of a general nature. This entails that the Minister may not give directives that are specific, as they have the impact of unduly limiting the local autonomy guaranteed by the Constitution. This discussion shows that, in some cases, supervisory powers under section 313 of UCA are being incorrectly used, for example through the issue of directives that are not of a general character. It is suggested that this practice is inconsistent not only with UCA but also with the Constitution. Thus section 313 may be declared unconstitutional.

\footnotetext{
${ }^{56}$ Id, sec 276(1).

57 J Mapuva and L Muyengwa-Mapuva "Devolution and the new constitutional dispensation in Zimbabwe" (5 March 2014), available at: <http://www.monitor.upeace.org/innerpg.cfm?id_article=1035> (last accessed 3 February 2017).

${ }^{58}$ Steytler and de Visser Local Government Law, above at note 10 at $1-15$.

${ }^{59}$ Id at $1-5$.

${ }^{60}$ See, for example, Constitution, preamble to chap 14, secs 264 and 265.
} 
Cooperative governance is a key theme of the Constitution, as are guarantees of local autonomy. The principle of cooperative governance requires that local governments be informed and consulted on matters that affect their activities and institutional integrity. This entails that the Constitution places an obligation on the national and provincial tiers of government to inform and consult local authorities on various matters which are of interest to local authorities, such as policy directives under section 313. Section 313 provides that the Minister merely has to inform the council concerned if he or she considers issuing a directive. ${ }^{61}$ Under the principle of cooperative governance, it is not sufficient merely to inform another state institution of a forthcoming policy, particularly when it has such significant consequences for that institution. It is suggested that the Minister must not only inform but also consult local authorities before issuing such policy directives. Hence, section 313 requires alignment with the Constitution by reflecting the new cooperative governance dimension.

\section{Conclusion}

National government supervision of local authorities is important to promote the realization of national and local goals, such as the efficient and effective delivery of basic services. The Urban Councils Act gives the central government a wide array of supervisory powers. The issuing of policy directives is one of the instruments used by the national government to ensure that the activities of urban local authorities are in line with national policies and objectives. When exercising the power to issue policy directives, it is important that the national government does not violate a local authority's "right to govern" as determined by the Constitution. The Constitution provides for devolution of power to local authorities to realize various objectives, including development and democracy. ${ }^{62}$ The Constitution further provides for certain principles and values, such as the right of communities to govern their own affairs, institutional integrity of local government and cooperative governance. ${ }^{63}$ These principles and values signify that supervision of local authorities by the national government must be exercised within limits. Thus, it is important that the national government exercises its supervisory powers in a way that does not unjustifiably undermine local autonomy and accountability. This article has, however, established that the exercise of supervisory powers under section 313 of UCA limits local autonomy in a number of ways. The overall effect of these powers is that they undermine the autonomy of urban local authorities, as the Minister has unlimited supervisory powers that he or she sometimes exercises incorrectly. To strike a balance between the requirement for supervision and the need for local autonomy, it is proposed that the discretion given to the Minister under section 313 be limited. First, the Minister's powers should be limited to issuing directives of a general character or nature, as defined in this article. Secondly, the grounds upon which the Minister may resort to a policy directive should be clearly spelt out and made dependent on objectively verifiable facts. Legislation should also require local authorities to be consulted before the Minister issues policy directives, so as to give

\footnotetext{
${ }^{61}$ UCA, sec 313.

${ }^{62}$ Constitution, sec 264.

${ }^{63} \mathrm{Id}$, secs 194, 264 and 276 respectively.
} 
local authorities an opportunity to make representations on matters that affect their interests. Lastly, it is recommended that the legal framework regulating the issue of policy directives makes it clear that the Minister is obliged to consider compliance or implementation costs before he or she issues a policy directive. 